\title{
Impact of different grazing systems for bovine cattle on the soil microbiological and chemical characteristics
}

\author{
Martha Regina Lucizano Garcia ${ }^{1}$, Alexandre Amstalden Moraes Sampaio ${ }^{2}$, Ely Nahas ${ }^{3}$ \\ ${ }^{1}$ Programa de Pós-Graduação em Microbiologia Agropecuária - FCAV/UNESP. \\ 2 Departamento de Zootecnia - FCAV/UNESP \\ ${ }^{3}$ Departamento de Produção Vegetal - FCAVIUNESP .
}

ABSTRACT - The objective of this work was to study the effect of grazing systems: rotational, continuous and the absence of cattle, in pastures of Brachiaria brizantha on microbial activity (respiratory, potential nitrification, solubilizing, and enzymatic) and on the chemical attributes (contents of organic carbon, total nitrogen, organic phosphorus, and moisture) of Eutrustox soil over one year. Eight Canchim breed animals were used. The samples were collected in the four seasons from 2005 to 2006. The average of organic C, organic P, and moisture contents, as well as potential nitrification and solubilizing activity and urease and acid phosphatase activities were significantly higher in the spring and/or summer than in autumn and/or winter. The total nitrogen amounts did not vary among seasons. While the respiratory activity was larger during winter and summer, cellulase activity was smaller during spring than in the other seasons. Except for organic P, higher values of the variables studied were observed in the rotational grazing. The results indicate that the hot and rainy season and the rotational grazing system cause increases in the soil microbiological and chemical attributes.

Key Words: cellulase, microbial respiratory activity, phosphatase, potential nitrification, urease

\section{Introduction}

Pastures can be considered as permanent crops because they are not submitted to management practices such as those observed for agricultural crops. In pasture soil, the carbon (C) input is higher than in cultivated areas (Schipper \& Sparling, 2000). The most important supply of nutrients to the pasture comes from the decomposition of plant residues and animal excreta. An animal excreta is equivalent to $1,200 \mathrm{~g}$ of dung and $200 \mathrm{ml}$ of urine (Allen et al., 1996). Excreta, mainly via faeces, increase the $C$ input and soil biochemical activities (Haynes \& Williams, 1999); have a low C:N ratio, manure is 20:1 and the urine of cattle is 3.9:1, allowing rapid mineralization (Whitehead, 2000); and accumulate in the soil, increasing organic matter stocks (Carran \& Theobald, 2000). Studies were conducted to evaluate the performance of Brachiaria on beef signal grass (Flores et al., 2008) and on the stocking rate of steers (Rezende et al., 2008). However, the effect of these systems on nutrient cycling has rarely been studied. Several microbial and biochemical analyses can be used to assess grazing impact on soil quality (Ingram et al., 2008).
The excreta of cattle in pastures have been shown to provide a 20 -fold increase in potential nitrification compared to control (Mueller et al., 2003). The activity of the enzymes protease, urease and acid phosphatase was higher in soils of grasslands in the presence of animals than in the control (Haynes \& Williams, 1999). Protease and phosphatase activities increased with the addition of organic matter in soil and they can be considered as resulting from the mineralization process catalysed by microorganisms (Rezende et al., 2004).

Phosphatases catalyse the transformation of organic phosphorus and may be affected by the fertilization of soil, vegetation and season (Staley et al., 2008). In a selfsustaining ecosystem such as pasture, the return of soluble phosphorus to plants may be due to the presence of inorganic phosphate solubilizing microorganisms in the soil (Barroso \& Nahas, 2005).

The aim of the present study was to evaluate the effect of different grazing systems (rotational, continuous and the absence of cattle) on the microbial activity responsible for the transformation of compounds related to the cycles of $\mathrm{C}, \mathrm{N}$ and $\mathrm{P}$, as well as on the chemical attributes of the pasture soil during a period of one year. 


\section{Material and Methods}

The experimental site is located at UNESP/Jaboticabal (21 ${ }^{\circ} 18^{\prime} 22^{\prime \prime} \mathrm{S}$ and $\left.48^{\circ} 18^{\prime} 58^{\prime \prime} \mathrm{W}\right)$, with an altitude of $595 \mathrm{~m}$, and, according to Köppen, subtropical type climate, with summer rains and dry winters. The mean annual precipitation is $1230 \mathrm{~mm}$ and the mean temperature is $21^{\circ} \mathrm{C}$, ranging from 17.4 to $29.4^{\circ} \mathrm{C}$, and with a relative humidity of 70\% (Figure 1).

The grazing systems evaluated were: rotational, a paddock grazed for five to six days; continuous, with the paddock continuously grazed by the animals; and no grazing (control), a pasture area with no animals. Each pasture for all systems studied was formed by five plots in a 3-ha area with eight animal units (AU, each animal unit corresponded to $450 \mathrm{~kg}$ ). The cattle used were of the Canchim breed (60\% Charolez $+40 \%$ Nellore). The rotational grazing system has been adopted as the management system since 1997 with the establishment of grass Brachiaria brizantha cv. marandu. Brachiaria was also the grass used in the other systems. Two tons of high-calcium lime ha- ${ }^{-1}$ were applied in the three systems. In the rainy season, nitrogen side-dress fertilizer (150 $\mathrm{kg} \mathrm{N} \mathrm{ha}^{-1} \mathrm{yr}^{-1}$ ) was applied. During the dry season, supplements of $25 \mathrm{~kg}$ of corn silage and $2.5 \mathrm{~kg}$ of concentrate (grains of corn and soybeans) per animal were used in the rotational and continuous grazing systems.
Samples of Eutrustox Soil (Embrapa, 2006) were randomly collected in the Autumn (first fortnight of April), Winter (first fortnight of July), Spring (second half of November) and Summer (first half of February) in the period 2005-2006 in all pastures. Each sample consisted of six sub-samples, taken from a $0-5 \mathrm{~cm}$ soil depth. Soil samples were transported to the laboratory, sieved ( $2 \mathrm{~mm}$ ) and homogenized. Each sample was divided into two parts: one part was kept at $7^{\circ} \mathrm{C}$ until analysis and the other part was air-dried and stored at room temperature.

Respiration rates in the soil were determined by incubating $100 \mathrm{~g}$ of soil in sealed jars containing vials with $20 \mathrm{~mL}$ water and $10 \mathrm{~mL}$ of $\mathrm{NaOH} 0.5 \mathrm{~mol} \mathrm{~L}^{-1}$ for seven days at $28^{\circ} \mathrm{C}$ (Rezende et al., 2004). The $\mathrm{CO}_{2}$ evolved from the soil was absorbed by $\mathrm{NaOH}$ and determined by titration with $\mathrm{HCl} 0.5 \mathrm{~mol} \mathrm{~L}^{-1}$ after the addition of $\mathrm{BaCl}_{2}$. Potential nitrification was determined by incubating the soil with and without the addition of $\left(\mathrm{NH}_{4}\right)_{2} \mathrm{SO}_{4}$ (160 $\mu \mathrm{g} \mathrm{N} \mathrm{g}^{-1}$ dry soil) for 21 days at $30^{\circ} \mathrm{C}$. Extraction of nitrate was performed with $50 \mathrm{ml} \mathrm{KCl} 1 \mathrm{~mol} \mathrm{~L}^{-1}$ for $60 \mathrm{~min}$ and $\mathrm{N}$ was determined by digestion and titration with $\mathrm{H}_{2} \mathrm{SO}_{4} 0.0025 \mathrm{~mol} \mathrm{~L}^{-1}$. The solubilizing activity of the soil was determined by incubating $10 \mathrm{~g}$ soil with and without the addition of $38.4 \mathrm{mg}$ fluorapatite $\mathrm{g}^{-1}$ dry soil for 30 days at $30^{\circ} \mathrm{C}$. Soluble phosphate was extracted by adding $12 \mathrm{~mL}$ $\mathrm{NaHCO}_{3} 0.5 \mathrm{~mol} \mathrm{~L}^{-1} \mathrm{pH} 8.5$ for 30 minutes and determined

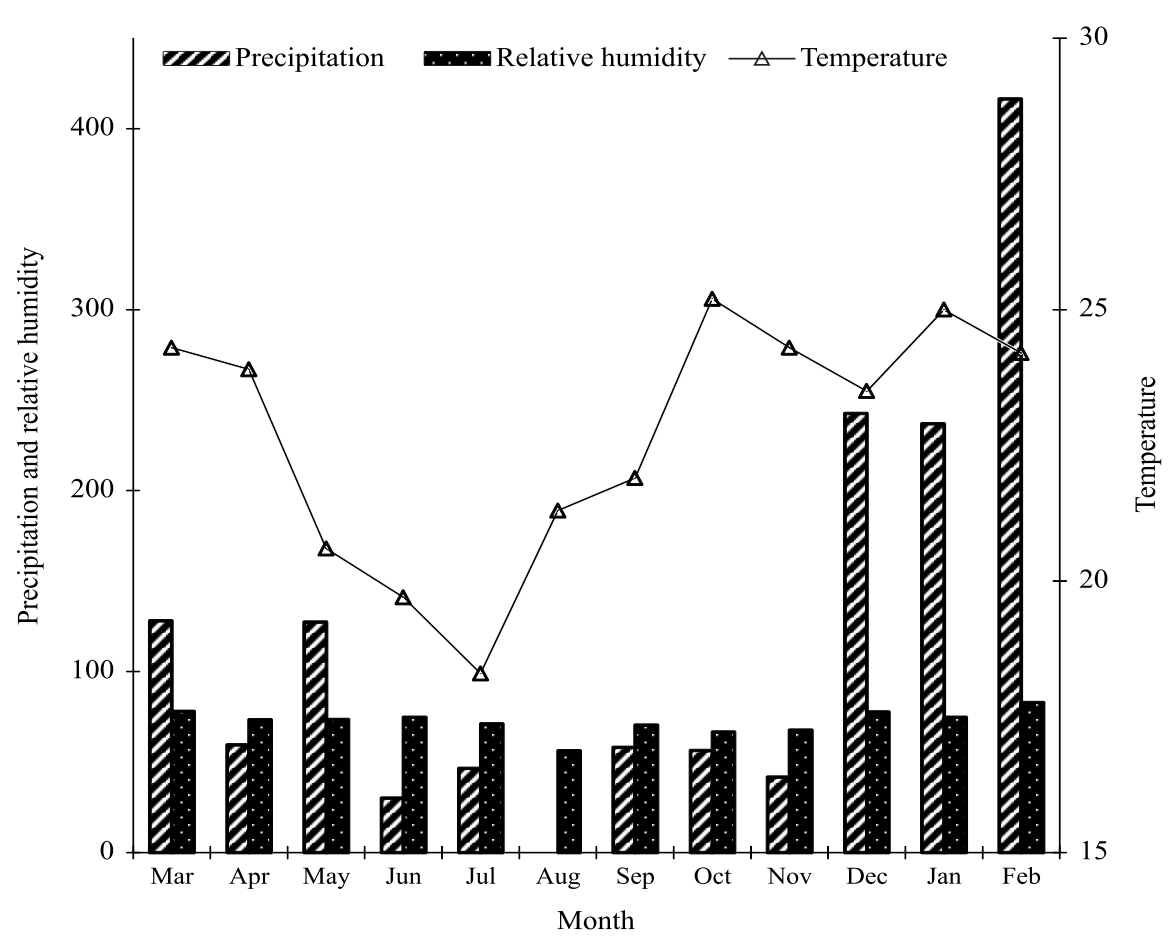

Figure 1 - Monthly variation in rainfall (mm), air temperature $\left({ }^{\circ} \mathrm{C}\right)$, and relative humidity (\%) from March 2005 to February 2006. 
by using an ascorbic acid solution. The nitrification and solubilizing activities were calculated as the difference between samples with or without added $\left(\mathrm{NH}_{4}\right)_{2} \mathrm{SO}_{4}$ or fluorapatite, respectively.

Cellulase activity was determined by incubating $1.0 \mathrm{~g}$ soil with $0.2 \mathrm{ml}$ toluene and $10 \mathrm{ml}$ substrate (CMC) for 4 h at $50^{\circ} \mathrm{C}$ (Kanazawa \& Miyashita, 1986). The glucose released was measured colourimetrically at $660 \mathrm{~nm}$ after a reaction with alkaline copper and arsenomolybdate. Urease activity was measured by incubating 2.0 g soil with $0.2 \mathrm{~mL}$ toluene, $2.0 \mathrm{~mL}$ of $\mathrm{KH}_{2} \mathrm{PO}_{4} 0.1 \mathrm{~mol} \mathrm{~L}^{-1} \mathrm{pH} 6.7$ and $1.0 \mathrm{~mL}$ of urea $10 \%(\mathrm{w} / \mathrm{v})$ for $3 \mathrm{~h}$ at $37^{\circ} \mathrm{C}$ (Mc Garity \& Myers, 1967). The $\mathrm{NH}_{4}{ }^{+}-\mathrm{N}$ released was quantified by the indophenol blue method using the reagents phenolate and hypochlorite. Acid phosphatase was determined by using $0.2 \mathrm{~g}$ of soil after the addition of p-nitrophenyl phosphate $4 \mathrm{mM} \mathrm{L}^{-1}$ acetate buffer $0.1 \mathrm{~mol} \mathrm{~L}^{-1}$, pH 5.4, and incubated at $37^{\circ} \mathrm{C}$ for $30 \mathrm{~min}$ (Rezende et al., 2004). The p-nitrophenol released was determined by using a spectrophotometer at $405 \mathrm{~nm}$. The specific activity of enzymes was expressed as micrograms of the reaction product per gram of dry soil.

Organic carbon was determined after the addition of potassium dichromate-sulphuric acid to the soil samples (Sims \& Haby, 1971) and total nitrogen by digestion of the soil samples with $\mathrm{H}_{2} \mathrm{SO}_{4}$. Soil organic phosphorus was determined after ignition (or not) of the soil samples and the $\mathrm{P}$ was extracted with $50 \mathrm{~mL} \mathrm{H}_{2} \mathrm{SO}_{4} 0.5 \mathrm{~mol} \mathrm{~L}^{-1}$. The moisture content was determined by drying the soil at $105^{\circ} \mathrm{C}$ until a constant weight was reached. The chemical composition of the soil was determined at the Soil Analysis Laboratory of the Department of Soils and Fertilizers, UNESP/Jaboticabal (Table 1).

The experimental design was a split plot design with three systems of cattle management (rotational grazing, continuous grazing and no grazing as the control) and the four seasons as sub-plots, with five replicates each. The $\mathrm{F}$ test was used to analysis of variance of the results. The Tukey test at 5\% probability was used to compare means of treatments, seasons and grazing systems.

Table 1 - Chemical and physical properties of the Eutrustox soil of pastures under three systems of grazing

\begin{tabular}{|c|c|c|c|c|}
\hline Properties & & Control & Rotational & Continuous \\
\hline $\mathrm{pH}$ & $\mathrm{CaCl}_{2}$ & 4.9 & 5.2 & 5.0 \\
\hline Organic matter & $\mathrm{g} \mathrm{dm}^{-3}$ & 24 & 26 & 24 \\
\hline $\mathrm{P}$ resin & $\mathrm{mg} \mathrm{dm}^{-3}$ & 17 & 13 & 10 \\
\hline $\mathrm{K}^{+}$ & $\mathrm{mmoLdm}^{-3}$ & 0.8 & 1.1 & 1.2 \\
\hline $\mathrm{Ca}^{2+}$ & $\mathrm{mmoLdm}^{-3}$ & 15 & 22 & 18 \\
\hline $\mathrm{Mg}^{2+}$ & $\mathrm{mmoLdm}^{-3}$ & 10 & 15 & 11 \\
\hline $\mathrm{H}^{+}+\mathrm{Al}^{3+}$ & mmoLdm ${ }^{-3}$ & 31 & 25 & 28 \\
\hline Sum of bases, $\mathrm{SB}(\mathrm{K}+\mathrm{Ca}+\mathrm{Mg})$ & mmoLdm ${ }^{-3}$ & 25.8 & 38.1 & 30.2 \\
\hline Cation exchange capacity, $\mathrm{T}(\mathrm{SB}+\mathrm{H}+\mathrm{Al})$ & mmoLdm ${ }^{-3}$ & 56.8 & 63.1 & 58.2 \\
\hline Soil base saturation $(\mathrm{SB} / \mathrm{T} \times 100)$ & $\%$ & 45 & 60 & 52 \\
\hline
\end{tabular}

\section{Results and Discussion}

A significant (Tukey test, $\mathrm{P}<0.05$ ) accumulation of organic carbon and soil moisture was found during the spring and summer in relation to autumn and winter (Table 2); however, no significant differences were observed in the total $\mathrm{N}$ contents due to the influence of the seasons.

The highest content of organic phosphorus was observed in spring, autumn and then in the summer compared to winter. The trend in the accumulation of the studied variables during the spring-summer compared to autumn-winter may be due to the increased production of Brachiaria, favoured by the soil moisture and heatstroke rate, allowing greater stocking rates of animals (Pereira et al., 2000; Almeida et al., 2002) and by the amount of rainfall and the temperatures that prevailed during these seasons (Figure 1). Depending on the type of cattle management, there may be a surplus of green mass and an increased root production of Brachiaria, contributing to increase in soil organic carbon. Moreover, there is a transfer of nutrients and organic matter such as manure and urine in the soil (Haynes \& Williams, 1999).

Except for the content of organic phosphorus, the average contents of the other variables were significantly higher in the rotational system than in the other systems (Table 2). The highest concentration of cattle and the amount of excreta in the rotational system compared to continuous grazing could have influenced these responses. A higher mass of grass production was found in the rotational grazing system because regrowth occurred during the rest period of the pasture when the 
animals were moved to another paddock. In continuous grazing, the grass regrowth was consumed by the cattle, resulting in a smaller regrowth rate than in the rotational grazing and lower production of vegetation.

The highest content of $\mathrm{CO}_{2}$ was observed in winter and this decreased significantly $(\mathrm{P}<0.05)$ from 22 to $40 \%$ in the other seasons (Figure $2 \mathrm{~A}$ ). $\mathrm{CO}_{2}$ production in summer was similar to that in autumn and higher than that found in spring $(\mathrm{P}<0.05)$.

$\mathrm{CO}_{2}$ evolution has been related to temporal variations in temperature and soil moisture (Petrone et al., 2008; Yue-Lin et al., 2008). In this study, the amount of rainfall and the temperatures in winter were the lowest (Figure 1). However, the sudden rainfall in July before soil sampling may have stimulated the latent microbial community to increase the production of $\mathrm{CO}_{2}$. For example, although there was a dry winter, the emission of $\mathrm{CO}_{2}$ in the pasture of Brachiaria was appreciable during the winter months when compared to the maximum reached in February (Varella et al., 2004).

The respiratory activity decreased significantly by $13-14 \%$ in the rotation system in relation to the other systems (Figure 2B). This was possibly caused by a greater availability of nutrients in this system, which is one of the most important factors governing microbial activity (Tiwari et al., 2002).

The potential nitrification predominated in the summer season and it decreased on average $(\mathrm{P}<0.05)$ by $77 \%$ in winter, $61 \%$ in spring and $34 \%$ in autumn (Figure 2C). The seasonal variation in potential nitrification was also observed in soil in China (Zhang et al., 2008). The averages were similar between continuous and rotational grazing, and decreased significantly in the ungrazed pasture (Figure 2D). The increase in potential nitrification may have been due to the organic matter input in these systems stimulating the community of microorganisms that catalyse the conversion of organic $\mathrm{N}$ to nitrate
(Mueller et al., 2003) and the increase in soil moisture favouring the growth of Brachiaria and its root exudates being released (Malý et al., 2002).

The solubilizing activity of inorganic phosphate was also high in summer and decreased considerably in winter (82\%) and autumn (74\%) (Figure 2E). In the spring season, it only decreased by $10 \%$ in relation to the summer, which was still significant. The solubilizing activity was higher $(\mathrm{P}<0.05)$ in ungrazed and rotational grazing systems compared to continuous grazing (Figure $2 \mathrm{~F}$ ). The availability of soluble phosphate is usually low in most soils in Brazil (Barroso \& Nahas, 2005). Due to the influence of environmental conditions and soil fertility, a significant increase in soluble phosphate was found by 1.1 to 5.5 times-fold during the spring-summer compared to autumn-winter. Due to the degradation of organic matter, a greater release of available phosphorus may have occurred as a result of organic acid production and subsequent mineral phosphate solubilization (El-Dewiny et al., 2006). This mechanism may have provided an increase by $41 \%$ in the solubilizing activity in the rotational grazing system compared to the continuous system due to the increased influx of organic matter from animal excreta, used as a source of carbon and energy.

The mean cellulase activity was significantly reduced in the spring in relation to the activities observed in the other seasons, which were all similar (Figure 3A).

The greatest decrease in cellulase activity was found during the spring in the rotational and continuous grazing systems. In contrast, the activities of urease and phosphatase were predominant in spring (Figure 3C, E); however, whereas urease activity became progressively reduced throughout summer, autumn and winter (Figure 3C), acid phosphatase activity decreased significantly by $16 \%$ in autumn, 39\% in summer and 57\% in winter (Figure 3E). Because these enzymes are mainly produced by microorganisms, these results indicate that environmental

Table 2 - Contents of moisture, organic carbon, total nitrogen, and organic phosphorus of the soil under three systems of grazing

\begin{tabular}{|c|c|c|c|c|}
\hline & Soil moisture (\%) & $\begin{array}{c}\text { Organic carbon } \\
\text { (mg C g }{ }^{-1} \text { dry soil) }\end{array}$ & $\begin{array}{c}\text { Total nitrogen } \\
\text { (mg } \mathrm{Ng}^{-1} \text { dry soil) }\end{array}$ & $\begin{array}{l}\text { Organic phosphorus } \\
\text { (mg P g } \mathrm{g}^{-1} \text { dry soil) }\end{array}$ \\
\hline \multicolumn{5}{|l|}{ Season } \\
\hline Autumn & $8.43 \mathrm{C}$ & 21.65B & $1.30 \mathrm{~A}$ & $0.23 \mathrm{~A}$ \\
\hline Winter & $9.22 \mathrm{C}$ & $21.80 \mathrm{~B}$ & $1.16 \mathrm{~A}$ & $0.13 \mathrm{C}$ \\
\hline Spring & $11.55 \mathrm{~B}$ & $37.35 \mathrm{~A}$ & $1.27 \mathrm{~A}$ & $0.25 \mathrm{~A}$ \\
\hline Summer & $14.37 \mathrm{~A}$ & $36.04 \mathrm{~A}$ & $1.18 \mathrm{~A}$ & $0.19 \mathrm{~B}$ \\
\hline \multicolumn{5}{|c|}{ Grazing systems } \\
\hline Control & $9.80 \mathrm{~b}$ & $24.42 c$ & $1.26 \mathrm{a}$ & $0.22 \mathrm{a}$ \\
\hline Rotational & $11.23 \mathrm{a}$ & $33.56 a$ & $1.27 \mathrm{a}$ & $0.20 \mathrm{~b}$ \\
\hline Continuous & $11.64 \mathrm{a}$ & $29.66 b$ & $1.15 \mathrm{~b}$ & $0.18 \mathrm{~b}$ \\
\hline
\end{tabular}

Means followed by the same capital letter (season) or lower case letters (grazing system) show no significant difference (Tukey test, $\mathrm{P}<0.05$ ). 


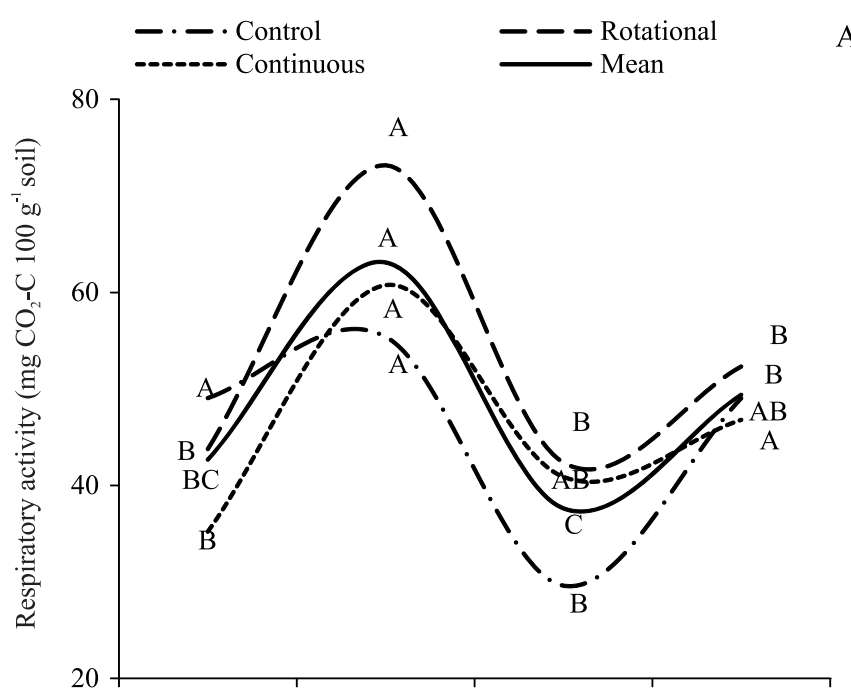

A

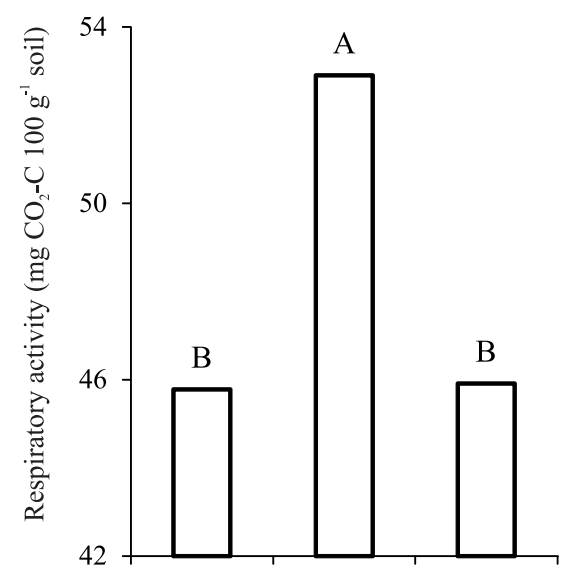

$\mathrm{C}$

$\mathrm{D}$
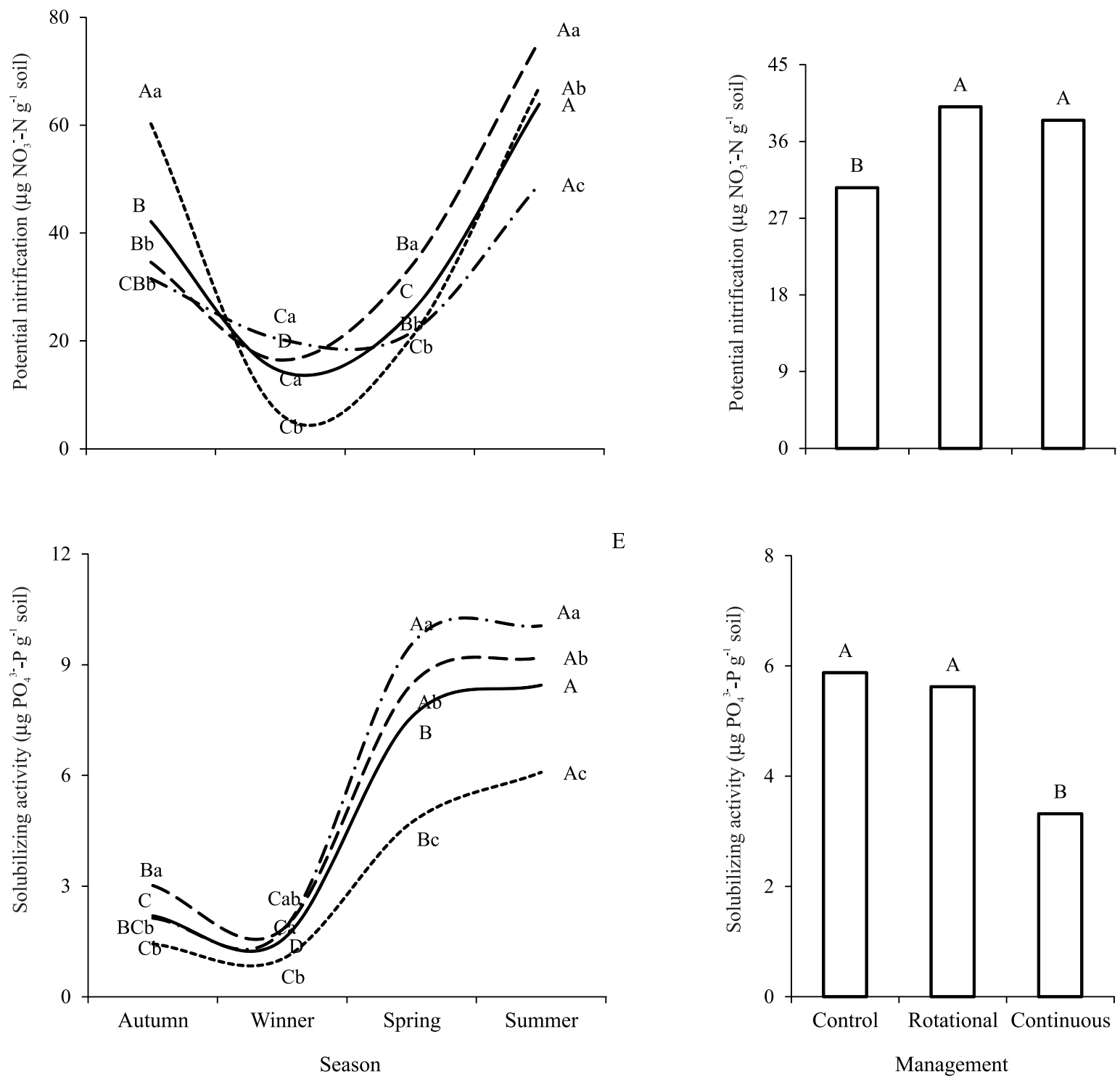

Figure 2 - Seasonal (A, C and E) and grazing system (B, D and F) effect on the respiratory activity, potential nitrification and solubilizing activity of the soil. Different letters indicate statistical significances at $\mathrm{P}<0.05$. 


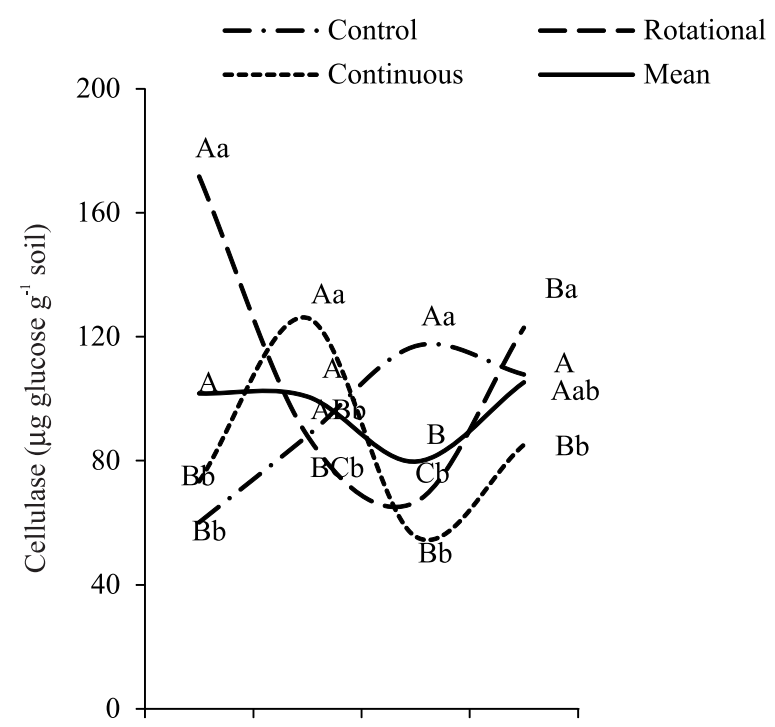

A

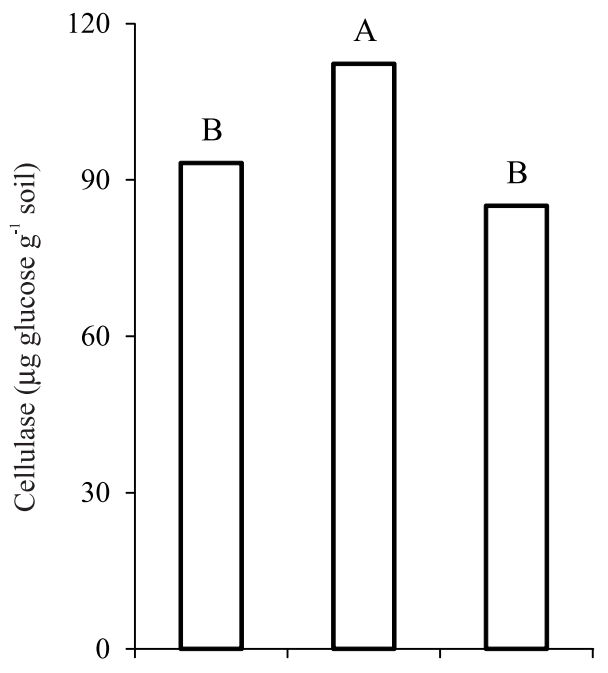

$\mathrm{C}$
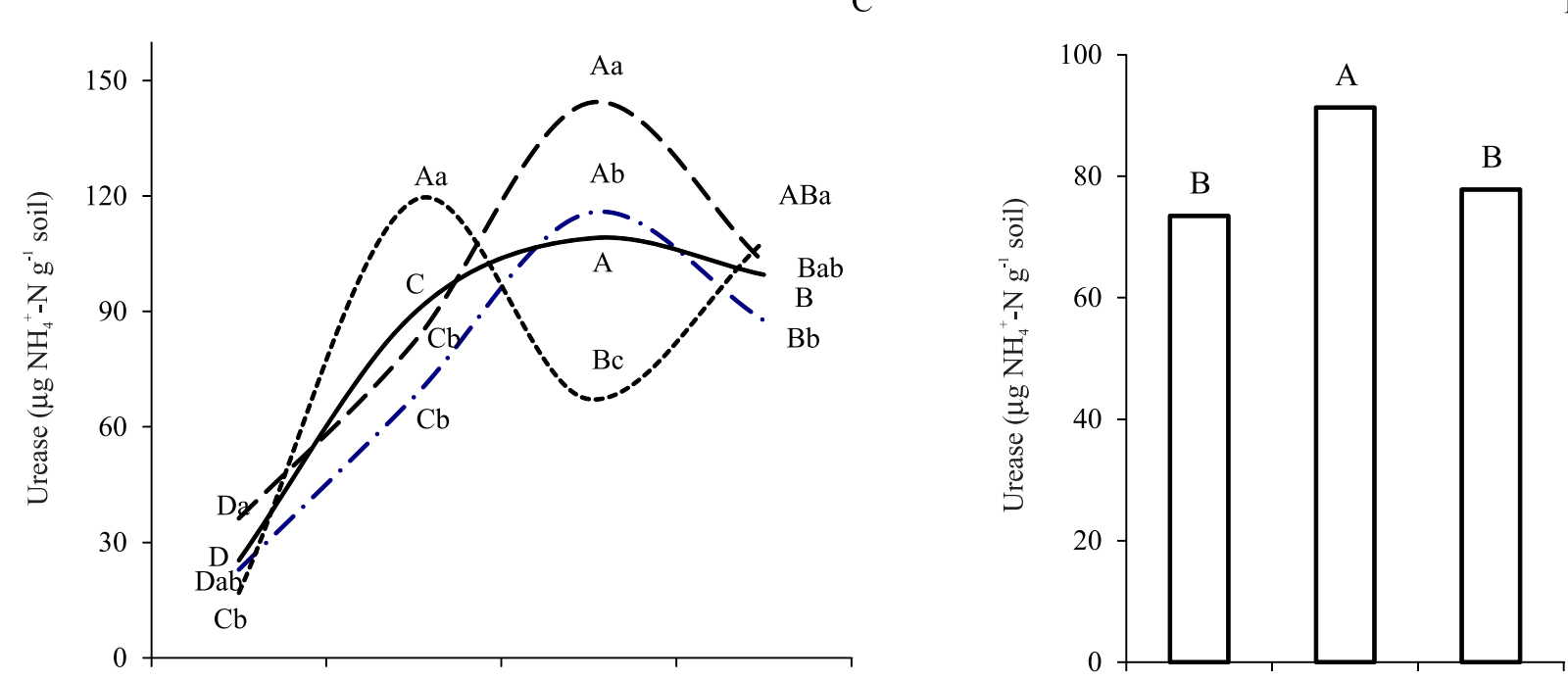

$\mathrm{E}$

$\mathrm{D}$
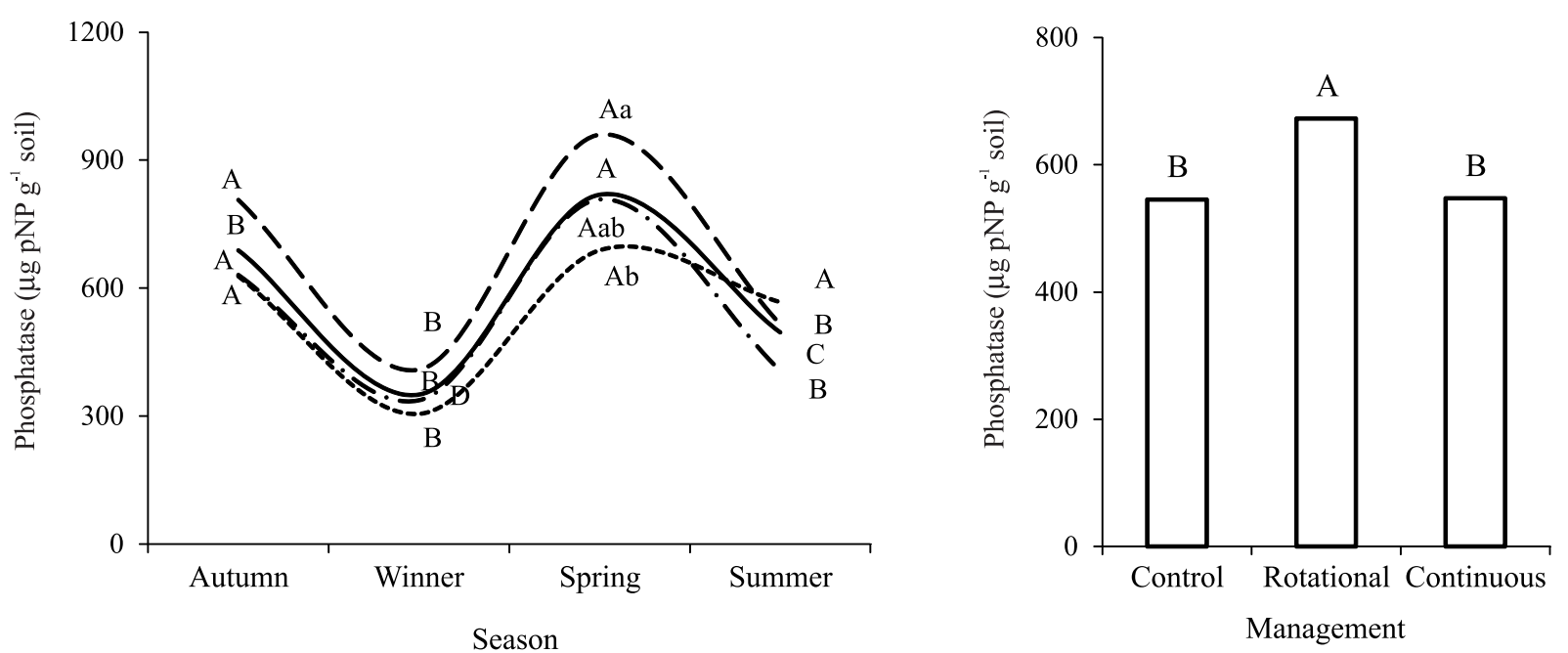

Figure 3 - Seasonal (A, C and E) and grazing system (B, D and F) effect on the enzymes cellulase, urease and phosphatase of the soil. Different letters indicate statistical significances at $\mathrm{P}<0.05$. 
factors (temperature and soil moisture) may have influenced microbial growth and stimulated the processes of soil C, $\mathrm{N}$ and P mineralization. The seasonal fluctuations in enzyme activity found in this study are in agreement with the results reported by Ralte et al. (2005) in relation to dehydrogenase and urease activity.

The rotation system promoted a higher $(\mathrm{P}<0.05)$ activity of these enzymes than the other systems (Figure 3B, D, F). The activity of urease and phosphatase may have been related to increased soil $\mathrm{C}$ because both increased in the spring. The effect of organic carbon on enzyme activity was previously reported by Saviozzi et al. (2001). These results contrast with those obtained by Malý et al. (2002), who concluded that urease activity remained constant throughout the year and it was weakly related to the mineralization of $\mathrm{N}$. With the increased availability of organic substrates and nutrients, the activity of protease, deaminase and urease enzymes, and microbial biomass, were stimulated (Cameron, 1999; Bol et al., 2003). Similar results were obtained by Haynes \& Williams (1999) who observed an increase in protease, histidase, urease, acid phosphatase and arylsulphatase activities in pastures with high concentrations of animals. This trend was also observed in the present study where the highest activities of cellulase, urease and phosphatase were found in rotational grazing, and which were significantly higher than those found in the control and continuous grazing systems. Decreasing activities of protease and urease have been reported in soil in the absence of grazing animals (Saviozzi et al., 2001; Bol et al., 2003), confirming our results.

\section{Conclusions}

The different cattle grazing systems and climatic conditions influence the microbiological and chemical characteristics of soil. Over the seasons, microbial activity and soil chemical properties increase, especially during spring and summer. From the different soil management systems, the rotational grazing system provides greater enzymatic and microbial activity and favours an increase in organic $\mathrm{C}$, total $\mathrm{N}$ and soil moisture contents.

\section{Acknowledgements}

This work was supported by FAPESP and Agrisus grants. We sincerely thank the fellowships from Agrisus (M.R.L.G.) and from CNPq (E.N.).

\section{References}

ALLEN, A.G.; JARVIS, S.C.; HEADON, D.M. Nitrous oxide emissions from soils due to inputs of nitrogen from excreta return by livestock on grazed grassland in the U.K. Soil Biology and Biochemistry, v.28, p.597-607, 1996.

ALMEIDA, R.G.; NASCIMENTO JÚNIOR, D.; EUCLIDES, V.P.B. et al. Produção animal em pastos consorciados sob três taxas de lotação, no Cerrado. Revista Brasileira de Zootecnia, v.31, n.2, p.852-857, 2002.

BARROSO, C.B.; NAHAS, E. The status of soil phosphate fractions and the ability of fungi to dissolve hardly soluble phosphates. Applied Soil Ecology, v.29, n.1, p.73-83, 2005.

BOL, R.; KANDELER, E.; AMELUNG, W. et al. Short-term effects of dairy slurry amendment on carbon sequestration and enzyme activities in a temperature grassland. Soil Biology and Biochemistry, v.35, n.11, p.1411-1421, 2003.

CAMERON, M.D. Field study of gross rates of $\mathrm{N}$ mineralization and nitrification and their relationships to microbial biomass and enzyme activities in soils treated with dairy effluent and ammonium fertilizer. Soil Use and Management, v.15, p.188-194, 1999.

CARRAN, R.A.; THEOBALD, P.W. Effects of excreta return on properties of a grazed pasture soil. Nutrient Cycling in Agroecosystems, v.56, p.79-85, 2000.

EL-DEWINY, C.Y.; MOURSY, KH.S.; EL-AILA, H.I. Effect of organic matter on the release and availability of phosphorus and their effects on spainch and radish plants. Research Journal of Agriculture and Biological Sciences, v.2, n.3, p.103-108, 2006.

EMPRESA BRASILEIRA DE PESQUISA AGROPECUÁRIA EMBRAPA. Sistema brasileiro de classificação do solo. Rio de Janeiro: Embrapa/CNPS, 2006. 412p.

FLORES, R.S.; EUCLIDES, V.P.B.; ABRÃO, M.P.C. et al. Desempenho animal, produção de forragem e características estruturais dos capins marandu e xaraés submetidos a intensidades de pastejo. Revista Brasileira de Zootecnia, v.37, n.8, p.1355-1365, 2008.

HAYNES, R.J.; WILLIAMS, P.H. Influence of stock camping behaviour on the soil microbiological and biochemical properties of grazed pastoral soils. Biology and Fertility of Soils, v.28, p.253-258, 1999.

INGRAM, L.J.; STAHL, P.D.; SCHUMAN, G.E. et al. Grazing impacts on soil carbon and microbial communities in a mixed-grass ecosystem. Soil Science Society of America Journal, v.72, n.4, p.939-948, 2008.

KANAZAWA, S.; MIYASHITA, K. A modified method for determination of cellulase activity in forest soil. Soil Science and Plant Nutrition, v.32, p.71-79, 1986.

MALÝ, S.; SARAPATKA, B.; KRSKOVÁ, M. Seasonal variability in soil $\mathrm{N}$ mineralization and nitrification as influenced by $\mathrm{N}$ fertilization. Rostlinná Výroba, v.48, n.9, p.389-396, 2002.

McGARITY, J.W.; MYERS, M.G. A survey of urease activity in soils of Northern New South Wales. Plant and Soil, v.27, p.217-238, 1967.

MÜLLER, C.; STEVENS, R.J.; LAUGHLIN, R.J. Evidence of carbon stimulated $\mathrm{N}$ transformations in grassland soil after slurry application. Soil Biology and Biochemistry, v.35, p.285-293, 2003.

PEREIRA, W.L.M.; VELOSO, C.A.C.; GAMA, J.R.N.F. Propriedades químicas de um Latossolo Amarelo cultivado com pastagens na Amazônia Oriental. Scientia Agricola, v.57, n.3, p.531-537, 2000.

PETRONE, R.M.; P. CHAHIL A, M.L. MACRAE B, M.C. Spatial variability of $\mathrm{CO}_{2}$ exchange for riparian and open grasslands within a first-order agricultural basin in Southern Ontario. Agriculture, Ecosystems and Environment, v.125, p.137-147, 2008.

RALTE, V.; PANDEY, H.N.; BARIK, S.K. et al. Changes in microbial biomass and activity in relation to shifting cultivation and horticultural practices in subtropical evergreen forest ecosystem of north-east India. Acta Oecologica, v.28, n.2, p.163-172, 2005. 
REZENDE, L.A.; ASSIS, L.C.; NAHAS, E. Carbon, nitrogen and phosphorus mineralization in two soils amended with distillery yeast. Bioresource Technology, v.94, n.2, p.159-167, 2004.

REZENDE, C.P.; PEREIRA, J.M.; PINTO, J.C. et al. Estrutura do pasto disponível e do resíduo pós-pastejo em pastagens de capimcameroon e capim-marandu. Revista Brasileira de Zootecnia, v.37, n.10, p.1742-1749, 2008.

SAVIOZZI, A.; LEVI-MINZI, R.; CARDELLI, R. et al. A comparison of soil quality in adjacent cultivated, forest and native grassland soils. Plant and Soil, v.233, n.2, p.251-259, 2001.

SCHIPPER, L.A.; SPARLING, G.P. Performance of soil condition indicators across taxonomic groups and land uses. Soil Science Society of America Journal, v.64, p.300-311, 2000.

SIMS, J.R.; HABY, V.A. Simplified colorimetric determination of soil organic matter. Soil Science, v.112, p.137-141, 1971.

STALEY, T.E.; GONZALEZ, J.M.; NEEL, J.P.S. Conversion of deciduous forest to silvopasture produces soil properties indicative of rapid transition to improved pasture. Agroforestry Systems, v.74, p.267-277, 2008.
STATISTICAL ANALYSIS SYSTEM - SAS. SAS procedures guide. Version 6. 3.ed. Cary: Statistical Analysis System Institute, 1990, 705p.

TIWARI, S.C.; SOROKHAIBAM, S.S.; DKHAR, M.S. et al. Soil degradation affects dehydrogenase activity and microbial biomass C in humid tropical forest soils of Arunachal Pradesh, NorthEastern India. Asian Journal of Microbiology, Biotechnology and Environmental Sciences, v.4, p.143-148, 2002.

VARELLA, R.F.; BUSTAMANTE, M.M.C.; PINTO, A.S. et al. Soil fluxes of $\mathrm{CO}_{2}$, $\mathrm{CO}, \mathrm{NO}$, and $\mathrm{N}_{2} \mathrm{O}$ from an old pasture and from native Savanna in Brazil. Ecological Applications, v.14, n.4, p.S221-S231, 2004.

WHITEHEAD, D.C. Nutrient elements in grassland soil-plantanimal relationships. Wallingford: CAB International, 2000. 369p.

YUE-LIN, L.; OTIENO, D.; OWEN, K. et al. Temporal variability in soil $\mathrm{CO}_{2}$ emission in an orchard forest ecosystem. Pedosphere, v.18, n.3, p.273-283, 2008.

ZHANG, X.; WANGA, Q.; LIA, L. et al. Seasonal variations in nitrogen mineralization under three land use types in a grassland landscape. Acta Oecologica, v.34, p.322-330, 2008. 